ISSN: 2302-8556

E-Jurnal Akuntansi Universitas Udayana

Vol.27.1.April (2019): 90-118

DOI: https://doi.org/10.24843/EJA.2019.v27.i01.p04

\title{
Pengaruh Penerapan GCG dan Budaya Tri Hita Karana pada Kinerja Keuangan LPD Di Kabupaten Jembrana
}

\author{
Ni Komang Abdi Tri Astini ${ }^{1}$ \\ I Ketut Yadnyana ${ }^{2}$
}

\author{
${ }^{1,2}$ Fakultas Ekonomi dan Bisnis Universitas Udayana (Unud), Bali, Indonesia. \\ e-mail: abditriastini97@gmail.com
}

\begin{abstract}
ABSTRAK
Tujuan penelitian ini adalah untuk mengetahui pengaruh penerapan good corporate governance dan budaya tri hita karana pada kinerja keuangan LPD di Kabupaten Jembrana. Penelitian ini dilakukan di seluruh LPD yang berada di Kabupaten Jembrana. Jumlah sampel yang digunakan adalah 61 LPD, dengan teknik non probability sampling dan metode saturation sampling (sampel jenuh). Pengumpulan data dilakukan melalui kuesioner dan observasi non participant. Teknik analisis yang digunakan adalah regresi linier berganda. Hasil pengujian hipotesis menunjukkan bahwa good corporate governance dan budaya tri hita karana secara parsial berpengaruh positif pada kinerja keuangan LPD di Kabupaten Jembrana. Hal ini menunjukkan bahwa semakin baik penerapan komponen good corporate governance dan budaya tri hita karana akan dapat meningkatkan kinerja keuangan LPD di Kabupaten Jembrana.

Kata kunci: Good corporate governance, budaya tri hita karana, kinerja keuangan
\end{abstract}

\begin{abstract}
The purpose of this study was to determine the effect of the application of good corporate governance and tri hita karana culture on the financial performance of LPD in Jembrana Regency. This research was conducted in all LPD in Jembrana regency. The number of samples used is 61 LPD, with non probability sampling techniques and saturation sampling methods. Data collection is done through questionnaires and non-participant observation. The analysis technique used is multiple linear regression. The results of hypothesis testing indicate that good corporate governance and the tri hita karana culture partially have a positive effect on the financial performance of LPD in Jembrana regency. This shows that the better implementation of the components of good corporate governance and the tri hita karana culture will be able to improve the financial performance of LPD in Jembrana regency.
\end{abstract}

Keywords: Good corporate governance, tri hita karana culture, financial performance

\section{PENDAHULUAN}

Kinerja keuangan merupakan salah satu alat ukur yang dapat digunakan oleh para stakeholders untuk mengukur atau menentukan tingkat kualitas perusahaan. Kinerja perusahaan dapat diketahui dari laporan keuangan perusahaan tersebut yang 
menunjukkan keadaan finansial yang dicapai perusahaan selama periode tertentu (Dewi dan Putri, 2014). Indikator yang digunakan dalam mengukur kinerja keuangan perbankan termasuk lembaga keuangan adalah profitabilitas (Siagian, 2011:51). Brigham dan Houston (2010:146) menjelaskan bahwa profitabilitas perusahaan, biasanya diukur menggunakan rasio profitabilitas karena sudah mencakup rasio utang, rasio aktivitas, maupun rasio likuiditas. Rasio profitabilitas yang sering digunakan adalah Return On Assets (ROA). ROA merupakan salah satu rasio keuangan yang digunakan untuk mengukur profitabilitas perusahaan secara menyeluruh. ROA dapat menunjukkan efisiensi dari aset yang digunakan dalam menghasilkan laba. Semakin tinggi nilai ROA, semakin baik pula kinerja perusahaan (Sarafina dan Saifi, 2017).

LPD merupakan lembaga keuangan milik desa pakraman yang berkedudukan di wewidangan desa pakraman. LPD diperlukan keberadaannya untuk menjamin perwujudan kesejahteraan masyarakat hukum adat yang merupakan krama desa pakraman (Peraturan Daerah Provinsi Bali Nomor 3 Tahun 2017). Secara umum LPD dapat dikatakan berhasil dalam menjalankan fungsi dan tujuannya, namun keberhasilan ini tidak dirasakan oleh seluruh LPD yang ada. Berdasarkan data dari Lembaga Pemberdayaan Lembaga Perkreditan Desa (LPLPD) Provinsi Bali tahun 2017, Kabupaten Jembrana memiliki total aset LPD terendah dibandingkan kabupaten/kota lainnya di Bali. Kabupaten Badung memiliki total aset LPD mencapai Rp5,9 triliun, Kabupaten Gianyar Rp3,6 triliun, Kota Denpasar Rp1,9 triliun, kabupaten Tabanan Rp1,4 triliun, Kabupaten Karangasem Rp1,2 triliun, Kabupaten 
ISSN: 2302-8556

E-Jurnal Akuntansi Universitas Udayana

Vol.27.1.April (2019): 90-118

Buleleng Rp1,9 triliun, Kabupaten Klungkung Rp743 miliar, Kabupaten Bangli Rp854 miliar, dan Kabupaten Jembrana Rp539 miliar (Kristianto, 2018).

Kordinator Lembaga Pemberdayaan Lembaga Perkreditan Desa (LPLPD) Kabupaten Jembrana menyatakan bahwa rendahnya aset LPD di Kabupaten Jembrana disebabkan karena beberapa faktor, salah satunya yaitu rendahnya tingkat kepercayaan masyarakat terhadap LPD di beberapa tempat dengan adanya kasus penyelewengan dana nasabah di LPD Ekasari Kecamatan Melaya pada tahun 2014 (Meitasari dan Budiasih, 2016). Kasus lainnya adalah adanya penggelapan uang nasabah hingga 80 juta rupiah oleh salah satu pegawai Lembaga Perkreditan Desa (LPD) Munduk Anyar, Kelurahan Tegalcangkring pada tahun 2016 (Ismadi, 2016). Kasus yang sama juga terjadi di LPD Mendoyo Dauh Tukad pada tahun 2017 dan uang nasabah yang digelapkan mencapai 134 juta rupiah (Baliberkarya.com, 2017).

Berdasarkan kasus yang dijelaskan, ini membuktikan bahwa sistem pengelolaan LPD masih kurang baik dan cara yang dapat digunakan untuk mengatasi hal tersebut adalah dengan menerapkan tata kelola perusahaan yang baik yang dikenal dengan istilah Good Corporate Governance (GCG). GCG dapat membantu dalam usaha pencegahan terjadinya skandal dalam perusahaan, kecurangan serta kejahatan yang berhubungan dengan hutang piutang dari organisasi (Todorovic, 2013). Halimatusadiah et al. (2015) dalam penelitiannya menunjukkan perusahaan di Indonesia sadar bahwa dengan menerapkan tata kelola perusahaan yang baik kinerja perusahaan akan menjadi lebih baik dan pada akhirnya meningkatkan profitabilitas 
mereka, serta akan menarik investor nasional dan investor internasional. GCG merupakan salah satu faktor kunci yang menentukan kesehatan sistem dan kemampuan setiap organisasi untuk bertahan dalam guncangan ekonomi (Sarbah dan Xiao, 2015). Penerapan komponen-komponen GCG merupakan suatu keharusan oleh karena itu tuntutan penerapan good corporate governance pada lembaga keuangan seperti LPD diharapkan nantinya akan membantu LPD ke arah yang lebih baik (Setyawan dan Putri, 2013).

LPD pada dasarnya adalah sebuah organisasi yang memiliki pandangan bahwa kinerjanya dipengaruhi oleh nilai-nilai baik yang berasal dari kekuatan diri, lingkungan kerja, serta hubungan antar sesama pegawai (Adiputra, 2014). Oleh karena itu, perlu dipertimbangkan adanya budaya lokal yang dapat dijadikan pedoman bagi setiap orang dan organisasi yang memahaminya. Sebuah falsafah kultur Bali yaitu Tri Hita Karana (THK) menyatakan bahwa masyarakat Hindu di Bali cenderung memandang diri dan lingkungannya sebagai suatu sistem yang dikendalikan oleh nilai keseimbangan, dan diwujudkan dalam bentuk perilaku (Gunawan, 2009). THK memiliki konsep bahwa hubungan harmonis merupakan hal yang penting dalam menjalankan suatu kegiatan atau organisasi. Hal tersebut menjadi tuntunan masyarakat dalam melakukan berbagai kegiatan yang melahirkan berbagai tindakan nyata yakni (a) keselarasan hubungan antara manusia dengan Ida Sang Hyang Widhi Wasa (Tuhan Yang Maha Esa) yang dikenal dengan istilah Parahyangan, (b) keselarasan hubungan dengan sesama manusia yang dikenal dengan istilah Pawongan, serta (c) keselarasan hubungan manusia dengan alam 
ISSN: 2302-8556

sekitar yang dikenal dengan istilah Palemahan. Selain itu juga didukung dengan adanya program Pemerintah Daerah Provinsi Bali yang menyelenggarakan Tri Hita Karana Awards yang semakin menumbuhkan implementasi ajaran THK dalam kehidupan sehari-hari terutama pada pekerjaan (Mustikayani dan Dwirandra, 2016).

Berdasarkan uraian diatas, maka menarik untuk diteliti pengaruh penerapan good corporate governance dan budaya tri hita karana pada kinerja keuangan Lembaga Perkreditan Desa di Kabupaten Jembrana.

Penelitian ini bertujuan untuk memperoleh bukti empiris mengenai pengaruh good corporate governance dan budaya tri hita karana pada kinerja keuangan Lembaga Perkreditan Desa di Kabupaten Jembrana. Penelitian ini diharapkan dapat memberikan manfaat bagi berbagai pihak diantaranya manfaat teoritis dan manfaat praktis. Manfaat teoritis yaitu penelitian ini diharapkan mampu memberikan tambahan referensi, informasi, dan wawasan lebih luas mengenai pengaruh penerapan good corporate governance dan budaya tri hita karana pada kinerja keuangan LPD di Kabupaten Jembrana. Manfaat praktis yaitu penelitian ini diharapkan mampu memberikan pertimbangan dalam rangka pengambilan keputusan atau pengambilan kebijakan bagi manajemen LPD serta dapat memberikan kontribusi praktis bagi pihak LPD dalam rangka meningkatkan kinerja dan kualitas LPD khususnya yang berada di Kabupaten Jembrana.

Robbins (1994:6) menjelaskan perkembangan organizational of fit theory diawali dengan adanya teori organisasi, yaitu teori yang menjelaskan bagaimana sebenarnya organisasi distruktur dan bagaimana organisasi dapat dikonstruksi guna 
meningkatkan keefektifan organisasi. Perkembangan selanjutnya adalah population ecology theory dan contigency yang kemudian menjadi sumber munculnya theory of fit, yaitu teori tentang keselarasan hubungan internal organisasi (Sobirin, 2007:268). Jadi, organizational of fit theory menyatakan bahwa strategi organisasi harus fit dengan faktor-faktor lain agar organisasi mencapai kinerja yang baik. Dengan demikian, agar suatu organisasi/perusahaan bisa hidup berkelanjutan, organisasi harus bisa hidup selaras atau menyesuaikan diri dengan lingkungan eksternal sehingga tujuan perusahaan secara umum dapat dicapai. Kemampuan perusahaan dalam menyesuaikan diri dengan faktor internal dan eksternal akan dapat meningkatkan kinerja perusahaan (Putri, 2012). Apabila pengelolaan perusahaan selaras dengan faktor internal (seperti good corporate governance) dan eksternal (budaya lokal) akan mampu mengurangi manajer melakukan tindakan yang oportunis dan selanjutnya berdampak pada nilai/kinerja perusahaan menjadi meningkat (Putri, 2012). Penelitian ini berpedoman pada organizational of fit theory. Faktor internal LPD dalam penelitian ini adalah good corporate governance dan faktor eksternalnya adalah budaya tri hita karana.

Lembaga Perkreditan Desa (LPD) merupakan lembaga keuangan milik desa pakraman yang berkedudukan di wewidangan desa pakraman. LPD diperlukan keberadaannya untuk menjamin perwujudan kesejahteraan masyarakat hukum adat yang merupakan krama desa pakraman (Peraturan Daerah Provinsi Bali Nomor 3 Tahun 2017). LPD merupakan salah satu lembaga keuangan di Bali yang memiliki dua karakteristik unik yaitu, (1) lembaga keuangan yang dimiliki dan diatur oleh desa 
ISSN: 2302-8556

adat serta terintegrasi penuh ke dalam budaya Bali dan (2) berbeda dengan lembaga keuangan lain yang meliputi hampir semua desa adat di Bali. Gunawan (2009) menyatakan bahwa LPD merupakan lembaga keuangan yang didirikan oleh desa adat dan berfungsi menghimpun kekayaan desa adat serta melaksanakan pemberdayaan ekonomi masyarakat desa pakraman di Bali.

Forum for Corporate Governance in Indonesia (FCGI) (2001) dalam publikasi yang pertama mempergunakan definisi Corporate Governance dari Cadbury Committee, yaitu seperangkat aturan yang mengatur hubungan antara pemegang saham (investor), pengelola (manajemen) perusahaan, kreditur, pemerintah, karyawan serta para stakeholder intern dan ekstern lainnya yang menyangkut hak-hak dan kewajiban mereka, atau merupakan suatu sistem yang mengatur dan mengendalikan perusahaan.

Komite Nasional Kebijakan Governance (2006) dalam Buku Pedoman Umum Good Corporate Governance Indonesia memaparkan lima komponen GCG yaitu transparency, accountability, responsibility, independency, dan fairness. Adapun maksud dari masing-masing komponen GCG tersebut adalah (1) transparency berkaitan dengan sikap perusahaan dalam menjaga objektivitas bisnisnya, (2) accountability merupakan sikap perusahaan dalam mempertanggungjawabkan kinerjanya, (3) responsibility merupakan keharusan perusahaan untuk menaati peraturan perundang-undangan, (4) independency merupakan sikap perusahaan yang tidak memiliki keterkaitan dengan pihak manapun, (5) fairness artinya perusahaan harus memperhatikan kepentingan pihak-pihak yang berkaitan dengan perusahaan. 
OECD (2004:13) menjelaskan lima tujuan utama corporate governance, yaitu (1) untuk mengurangi kesenjangan antara pihak-pihak yang berkepentingan dalam perusahaan seperti pemegang saham mayoritas dan pemegang saham minoritas, (2) meningkatkan kepercayaan investor dalam berinvestasi, (3) mengurangi biaya modal perusahaan, (4) meyakinkan semua pihak mengenai komitmen legal dalam pengelolaan perusahaan, (5) meningkatkan nilai perusahaan serta memperhatikan hubungan antara para stakeholders seperti kreditur, investor, karyawan perusahaan, bondholders, dan pemerintah.

Forum for Corporate Governance in Indonesia (FCGI, 2001) menyatakan bahwa terdapat beberapa manfaat yang bisa diperoleh dengan menerapkan corporate governance yaitu (1) meningkatkan kinerja perusahaan yang dicapai dengan terciptanya pengambilan keputusan yang lebih baik, meningkatnya efisiensi operasional, serta lebih meningkatnya pelayanan kepada stakeholders, (2) mempermudah diperolehnya dana pembiayaan yang lebih murah, (3) mengembalikan kepercayaan investor untuk menanamkan modalnya, (4) meningkatkan kepuasan pemegang saham dengan kinerja perusahaan melalui peningkatan shareholders value dan dividen.

Budaya Tri Hita Karana (THK) adalah sebuah filosofi yang sekaligus menjadi konsep kehidupan dan sistem kebudayaan masyarakat di Bali. Pedoman kehidupan yang berdasarkan pada prinsip keselarasan, kebersamaan, serta keseimbangan antara tujuan ekonomi, kelestarian lingkungan dan budaya, estetika dan spiritual (Tenaya, 2007). Riana (2011) menyatakan bahwa konsep tri hita karana yang berkembang di 
ISSN: 2302-8556

Bali merupakan konsep budaya yang berakar dari ajaran agama dan bersumber dari kitab suci agama Hindu yaitu Baghawad Gita. THK menurut Rahayu dkk. (2016) adalah sistem kebudayaan yang mengandung elemen parahyangan (hubungan harmonis antara manusia dengan Tuhan Yang Maha Esa), palemahan (hubungan harmonis antara manusia dengan lingkungannya), dan pawongan (hubungan harmonis antara manusia dengan manusia). THK telah dijadikan filosofi hidup yang bersifat holistik dan unik yang ada di Bali. THK merupakan budaya masyarakat Bali yang dibawa oleh individu pekerja, pimpinan, pemilik, dan pendiri perusahaan dalam aktivitas rutin di tempat kerjanya (Ariyanto dkk., 2017). Berdasarkan hal tersebut, maka budaya THK dapat dijadikan sebagai suatu tata nilai dan pegangan bagi anggota organisasi dalam berperilaku serta melaksanakan kewajiban, tugas, serta tanggungjawabnya dalam organisasi (Suardikha, 2013).

Menurut Mulyadi (2007:337), definisi kinerja adalah keberhasilan personil, tim, atau unit organisasi dalam mewujudkan sasaran strategik yang telah ditetapkan sebelumnya dengan perilaku yang diharapkan. Sedangkan penilaian kinerja adalah penentuan secara periodik efektivitas operasional suatu organisasi, bagian organisasi dan karyawan berdasarkan sasaran, standar dan kinerja yang telah ditetapkan sebelumnya. Sucipto (2003) menyatakan bahwa kinerja keuangan dapat diartikan sebagai penentuan ukuran-ukuran tertentu yang dapat mengukur keberhasilan suatu perusahaan dalam menghasilkan laba. Menurut Siagian (2011:51), indikator yang digunakan dalam mengukur kinerja keuangan perbankan termasuk lembaga keuangan seperti LPD adalah profitabilitas. Brigham dan Houston (2010:146) menjelaskan 
profitabilitas perusahaan, biasanya diukur menggunakan rasio profitabilitas karena sudah mencakup rasio utang, rasio aktivitas, dan rasio likuiditas. Profitabilitas perusahaan umumnya dianggap sebagai prasyarat penting untuk keberhasilan dan kelangsungan hidup perusahaan dalam jangka panjang (Yandazfar, 2013). ROA merupakan salah satu rasio keuangan yang digunakan untuk mengukur profitabilitas perusahaan secara menyeluruh. ROA dapat menunjukkan efisiensi dari aset yang digunakan dalam menghasilkan laba. Semakin tinggi nilai ROA, semakin baik pula kinerja perusahaan (Sarafina dan Saifi, 2017).

Good Corporate Governance (GCG) merupakan suatu konsep tata kelola perusahaan yang menjelaskan hubungan antara pihak-pihak yang berkepentingan dengan perusahaan dalam upaya perbaikan kinerja perusahaan. Menerapkan sistem tata kelola yang baik pada organisasi sudah didukung dengan dikeluarkannya Pedoman Umum Good Corporate Governance Indonesia oleh Komite Nasional Kebijakan Governance (KNKG) pada tahun 2006. Dewi dan Putri (2014) melakukan penelitian tentang pengaruh penerapan prinsip good corporate governance pada kinerja keuangan LPD di Kabupaten Gianyar. Hasil analisis menunjukkan bahwa penerapan prinsip good corporate governance berpengaruh positif pada kinerja keuangan LPD di Kabupaten Gianyar. Penelitian tersebut selaras dengan hasil penelitian Setyawan dan Putri (2013) yang menunjukkan bahwa penerapan good corporate governance memberikan pengaruh yang positif dan signifikan terhadap kinerja keuangan LPD. Hal tersebut serupa dengan hasil penelitian Soti dan Gupta (2013); Sami et al. (2011); Frediawan (2008); Ristifani (2009); Hindistari dan Putri 
ISSN: 2302-8556

(2016); Klapper dan Love (2002) yang menemukan GCG berpengaruh terhadap kinerja perusahaan. Dengan adanya penerapan GCG secara normatif akan mampu mengurangi perilaku oportunis manajemen. Berdasarkan uraian diatas, maka rumusan hipotesis yang diajukan sebagai berikut.

$\mathrm{H}_{1}$ : Good Corporate Governance berpengaruh positif pada kinerja keuangan LPD di Kabupaten Jembrana

Budaya THK merupakan kearifan lokal masyarakat Bali yang dipergunakan sebagai landasan bagi individu dalam setiap aktivitasnya, khususnya pada masyarakat desa pakraman yang merupakan pemilik LPD. Konsep kehidupan yang baik berdasarkan pada prinsip keselarasan, kebersamaan, dan keseimbangan antara tujuan ekonomi, kelestarian lingkungan dan budaya, estetika dan spiritual (Tenaya, 2007). Pentingnya menerapkan filosofi THK ini dalam organisasi telah dibuktikan dengan adanya penelitian-penelitian empiris yang berkaitan dengan hal tersebut. Penelitian yang dilakukan oleh Ehtesham et al. (2011) dan Ozigbo (2013) yang mendapatkan hasil bahwa budaya berpengaruh positif signifikan pada kinerja perusahaan. Penelitian Surya et al. (2014); Sastra dan Erawati (2017); Putri dkk. (2017) juga memperoleh hasil budaya THK berpengaruh positif pada kinerja perusahaan. Hasil tersebut juga didukung oleh penelitian Ahrens dan Mollona (2007); Hofstede et al. (1990); Indrianto (2000) yang menemukan bahwa budaya organisasi berpengaruh terhadap kinerja organisasi. Berdasarkan uraian di atas, maka dapat dirumuskan hipotesis sebagai berikut.

$\mathrm{H}_{2}$ : Budaya Tri Hita Karana berpengaruh positif pada kinerja keuangan LPD di Kabupaten Jembrana 


\section{METODE PENELITIAN}

Penelitian ini menggunakan pendekatan kuantitatif berbentuk asosiatif. Pendekatan kuantitatif adalah metode penelitian yang digunakan untuk meneliti populasi atau sampel tertentu yang bertujuan menguji hipotesis yang telah ditetapkan. Penelitian berbentuk asosiatif adalah penelitian yang bertujuan untuk mengetahui hubungan antara dua variabel atau lebih (Sugiyono, 2017:37). Variabel yang digunakan dalam penelitian ini yaitu variabel independen meliputi good corporate governance dan budaya tri hita karana, serta variabel dependen yaitu kinerja keuangan LPD. Secara skematis penelitian ini dapat disajikan seperti berikut.

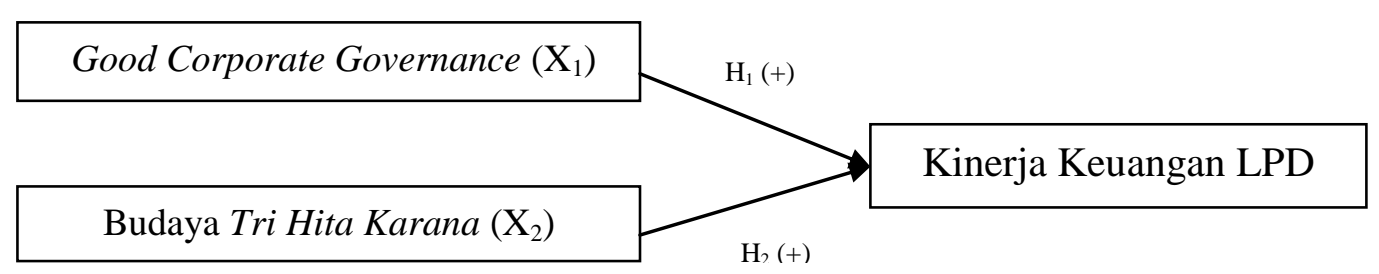

\section{Gambar 1. Desain Penelitian}

Sumber: Data diolah, 2018

Penelitian ini dilakukan pada seluruh Lembaga Perkreditan Desa (LPD) yang berada di Kabupaten Jembrana. Obyek dalam penelitian ini adalah kinerja keuangan pada Lembaga Perkreditan Desa di Kabupaten Jembrana yang dijelaskan oleh variabel good corporate governance dan budaya tri hita karana. Variabel good corporate governance dalam penelitian ini akan diukur menggunakan instrumen yang telah dimodifikasi dari kuesioner penelitian Putri (2013) dengan lima komponen utama yaitu transparansi, akuntabilitas, responsibilitas, independensi dan kewajaran, yang didalamnya memuat 19 butir pernyataan. 
ISSN: 2302-8556

Variabel budaya tri hita karana dalam penelitian ini akan diukur menggunakan instrumen yang telah dimodifikasi dari kuesioner penelitian Suardhika (2011) dengan tiga komponen yaitu parahyangan, pawongan, dan palemahan yang didalamnya memuat 12 butir pernyataan. Setiap kuesioner variabel bebas (X) dalam penelitian ini diukur menggunakan skala likert 4 titik. Variabel kinerja keuangan dalam penelitian ini diukur menggunakan rasio return on asset (ROA).

Populasi pada penelitian ini adalah seluruh LPD di Kabupaten Jembrana yang terdaftar di LPLPD Kabupaten Jembrana yaitu berjumlah 64 LPD. Sampel pada penelitian ini menggunakan teknik pengambilan sampel non probability sampling dengan metode saturation sampling (sampel jenuh). Jadi jumlah sampel penelitian ini yaitu 64 LPD. Responden dalam penelitian ini adalah Kepala LPD di Kabupaten Jembrana. Jenis data yang digunakan dalam penelitian ini adalah data kuantitatif dan data kualitatif. Sumber data dalam penelitian ini adalah sumber primer dan sumber sekunder. Data dalam penelitian ini diperoleh dengan menggunakan metode pengumpulan data yakni dengan kuesioner dan observasi non participant. Untuk menghasilkan data yang relevan, maka instrumen ini perlu dilakukan pengujian instrumen terlebih dahulu yang terdiri dari uji validitas dan uji reliabilitas.

Teknik analisis data yang digunakan dalam penelitian ini adalah analisis regresi linier berganda (multiple liniar regression analysis). Sebelum dilakukan analisis regresi linier berganda, maka terlebih dahulu dilakukan uji asumsi klasik 
yang terdiri atas uji normalitas, uji multikolinearitas, dan uji heteroskedastisitas. Adapun persamaan regresi yang digunakan adalah:

$\mathrm{Y}=\alpha+\beta_{1} \mathrm{X}_{1}+\beta_{2} \mathrm{X}_{2}+e$

Keterangan:

$\begin{array}{ll}\mathrm{Y} & =\text { Kinerja Keuangan LPD } \\ \alpha & =\text { Konstanta } \\ \beta_{1}, \beta_{2} & =\text { Koefisien regresi } \\ \mathrm{X}_{1} & =\text { Good Corporate Governance } \\ \mathrm{X}_{2} & =\text { Budaya Tri Hita Karana } \\ e & =\text { Error term }\end{array}$

Untuk menyelesaikan analisis data ini secara keseluruhan digunakan program SPSS dan semua hasil output data yang dihasilkan kemudian diinterpretasikan satu persatu, termasuk didalamnya melakukan uji koefisien determinasi $\left(R^{2}\right)$, uji kelayakan model (uji statistik F), dan uji Signifikansi Parameter Individual (Uji Statistik t).

\section{HASIL DAN PEMBAHASAN}

Penelitian ini menggunakan sampel sebanyak 64 LPD yang berada di Kabupaten Jembrana, dengan Kepala LPD sebagai respondennya. Berdasarkan observasi penelitian yang dilakukan, terdapat tiga LPD yang tidak beroperasi dan tidak melaporkan laporan keuangan pada tahun 2017 yaitu LPD Mendoyo Dauh Tukad, LPD Delod Berawah, dan LPD Lokasari, sehingga jumlah sampel penelitian menjadi 61 LPD dan 61 Kepala LPD sebagai responden. Data dikumpulkan dengan 
ISSN: 2302-8556

menyebarkan kuesioner secara langsung ke 61 LPD di Kabupaten Jembrana. Rincian pengiriman dan pengembalian kuesioner penelitian ini dapat dilihat pada Tabel 1.

Tabel 1.

Pengiriman dan Pengembalian Kuesioner

\begin{tabular}{lcc}
\hline \multicolumn{1}{c}{ Keterangan } & Jumlah & Persentase (\%) \\
\hline Kuesioner yang disebarkan & 61 & 100 \\
Kuesioner yang tidak kembali & 0 & 0 \\
Kuesioner yang dikembalikan & 61 & 100 \\
Kuesioner yang gugur (tidak lengkap) & 0 & 0 \\
Kuesioner yang digunakan & 61 & 100 \\
Tingkat pengembalian (response rate) & $61 / 61 \times 100 \%$ & 100 \\
Tingkat pengembalian yang digunakan & $61 / 61 \times 100 \%$ & 100 \\
(usable response rate) & & \\
\hline Sumber: Data diolah, 2018 & &
\end{tabular}

Berdasarkan Tabel 1 dapat diketahui bahwa dari 61 kuesioner yang disebar kepada responden, semua kuesioner tersebut kembali dengan pengisian yang lengkap dan memenuhi syarat sehingga semua kuesioner dapat digunakan. Perhitungan dari data tersebut menunjukkan tingkat pengembalian (response rate) sebesar $100 \%$, dengan tingkat pengembalian yang digunakan (usable response rate) sebesar $100 \%$.

Karakteristik responden dalam penelitian ini merupakan profil dari 61 responden yang mengisi kuesioner penelitian. Karakteristik responden berdasarkan jenis kelamin menunjukkan bahwa jumlah responden pria sebanyak 58 orang $(95,1 \%)$ dan jumlah responden wanita sebanyak 3 orang (4,9\%). Karakteristik responden berdasarkan usianya menunjukkan bahwa responden yang berusia $\leq 30$ tahun sebanyak 5 orang $(8,2 \%)$ dan jumlah responden yang berusia $>30$ tahun sebanyak 56 orang (91,8\%). Karakteristik responden berdasarkan pendidikan terakhir menunjukkan bahwa responden yang memiliki pendidikan terakhir pada jenjang 
SMA sebanyak 45 orang (73,8\%), Diploma sebanyak 3 orang (4,9\%), S1 sebanyak 12 orang $(19,7 \%)$, dan pendidikan terakhir pada jenjang S2 sebanyak 1 orang $(1,6 \%)$.

Uji validitas dilakukan dengan menghitung nilai pearson correlation yaitu mengkorelasikan antara skor faktor dengan skor total. Butir pernyataan yang digunakan dikatakan valid apabila korelasi tiap faktor bernilai positif dan lebih dari 0,30. Hasil uji validitas dapat dilihat pada Tabel 2.

Tabel 2. Hasil Uji Validitas

\begin{tabular}{|c|c|c|c|c|}
\hline No & Variabel & $\begin{array}{c}\text { Kode } \\
\text { Instrumen }\end{array}$ & $\begin{array}{c}\text { Nilai Pearson } \\
\text { Correlation }\end{array}$ & Keterangan \\
\hline \multirow[t]{19}{*}{1} & Good Corporate Governance $\left(\mathrm{X}_{1}\right)$ & $\mathrm{X}_{1.1}$ & 0,563 & Valid \\
\hline & & $\mathrm{X}_{1.2}$ & 0,709 & Valid \\
\hline & & $\mathrm{X}_{1.3}$ & 0,631 & Valid \\
\hline & & $\mathrm{X}_{1.4}$ & 0,560 & Valid \\
\hline & & $\mathrm{X}_{1.5}$ & 0,732 & Valid \\
\hline & & $\mathrm{X}_{1.6}$ & 0,642 & Valid \\
\hline & & $\mathrm{X}_{1.7}$ & 0,619 & Valid \\
\hline & & $\mathrm{X}_{1.8}$ & 0,612 & Valid \\
\hline & & $\mathrm{X}_{1.9}$ & 0,678 & Valid \\
\hline & & $\mathrm{X}_{1.10}$ & 0,636 & Valid \\
\hline & & $\mathrm{X}_{1.11}$ & 0,707 & Valid \\
\hline & & $\mathrm{X}_{1.12}$ & 0,584 & Valid \\
\hline & & $\mathrm{X}_{1.13}$ & 0,479 & Valid \\
\hline & & $\mathrm{X}_{1.14}$ & 0,664 & Valid \\
\hline & & $\mathrm{X}_{1.15}$ & 0,724 & Valid \\
\hline & & $\mathrm{X}_{1.16}$ & 0,635 & Valid \\
\hline & & $\mathrm{X}_{1.17}$ & 0,746 & Valid \\
\hline & & $\mathrm{X}_{1.18}$ & 0,596 & Valid \\
\hline & & $\mathrm{X}_{1.19}$ & 0,746 & Valid \\
\hline \multirow[t]{12}{*}{2} & Budaya Tri Hita Karana $\left(\mathrm{X}_{2}\right)$ & $\mathrm{X}_{2.1}$ & 0,800 & Valid \\
\hline & & $\mathrm{X}_{2.2}$ & 0,690 & Valid \\
\hline & & $\mathrm{X}_{2.3}$ & 0,868 & Valid \\
\hline & & $\mathrm{X}_{2.4}$ & 0,793 & Valid \\
\hline & & $\mathrm{X}_{2.5}$ & 0,706 & Valid \\
\hline & & $\mathrm{X}_{2.6}$ & 0,734 & Valid \\
\hline & & $\mathrm{X}_{2.7}$ & 0,723 & Valid \\
\hline & & $\mathrm{X}_{2.8}$ & 0,753 & Valid \\
\hline & & $\mathrm{X}_{2.9}$ & 0,789 & Valid \\
\hline & & $\mathrm{X}_{2.10}$ & 0,689 & Valid \\
\hline & & $\mathrm{X}_{2.11}$ & 0,647 & Valid \\
\hline & & $\mathrm{X}_{2.12}$ & 0,721 & Valid \\
\hline
\end{tabular}

Sumber: Data diolah, 2018 
ISSN: 2302-8556

Berdasarkan Tabel 2. dapat diketahui bahwa seluruh instrumen yang digunakan untuk mengukur variabel penelitian yaitu good corporate governance dan budaya tri hita karana adalah valid. Hal ini dibuktikan dengan nilai pearson correlation tiap instrumen pernyataan yang diperoleh lebih besar dari 0,30 .

Uji reliabilitas dilakukan dengan uji statistik cronbach alpha. Suatu instrumen dikatakan reliabel jika nilai cronbach's alpha $>70$. Hasil uji reliabilitas dapat dilihat pada Tabel 3.

Tabel 3.

Hasil Uji Reliabilitas

\begin{tabular}{lcc}
\hline \multicolumn{1}{c}{ Variabel } & Cronbach's Alpha & Keterangan \\
\hline Good Corporate Governance $\left(\mathrm{X}_{1}\right)$ & 0,920 & Reliabel \\
Budaya Tri Hita Karana $\left(\mathrm{X}_{2}\right)$ & 0,925 & Reliabel \\
\hline Sumber: Data diolah, 2018 & &
\end{tabular}

Berdasarkan Tabel 3 dapat diketahui bahwa seluruh instrumen penelitian adalah reliabel dan layak digunakan untuk mengumpulkan data. Hal ini dibuktikan dengan nilai cronbach's alpha dari kedua variabel bebas (X) lebih besar dari 0,70.

Statistik deskriptif dalam penelitian ini memberikan informasi tentang nilai minimum (minimum), maksimum (maximum), nilai rata-rata (mean), dan standar deviasi (std. deviation). Hasil statistik deskriptif dalam penelitian ini dapat dilihat dalam Tabel 4.

Tabel 4. Hasil Uji Statistik Deskriptif

\begin{tabular}{lccccc}
\hline \multicolumn{1}{c}{ Variabel } & N & Minimum & Maximum & Mean & $\begin{array}{c}\text { Std. } \\
\text { Deviation }\end{array}$ \\
\hline Good Corporate Governance & 61 & 52,00 & 76,00 & 64,72 & 6,28 \\
Budaya Tri Hita Karana & 61 & 36,00 & 48,00 & 41,21 & 1,89 \\
Kinerja Keuangan & 61 & 0,34 & 10,02 & 3,91 & 1,72 \\
\hline Sumber: Data diolah, 2018 & \multicolumn{6}{c}{}
\end{tabular}

Kinerja Keuangan
Sumber: Data diolah, 2018 
Berdasarkan Tabel 4 dapat diketahui data hasil uji statistik deskriptif yang meliputi nilai minimum, maksimum, mean, dan standar deviasi dari masing-masing variabel, dengan $\mathrm{N}$ yang menunjukkan banyaknya data yang diuji yaitu berjumlah 61 data. Misalkan, nilai minimum untuk variabel good corporate governance sebesar 52,00, nilai maksimum sebesar 76,00, nilai rata-rata sebesar 64,72 dan terjadi penyimpangan nilai good corporate governance terhadap nilai rata-ratanya sebesar 6,28 yang ditunjukkan dengan nilai standar deviasinya. Begitu pula dengan variabel budaya tri hita karana dan variabel kinerja keuangan.

Uji normalitas dilakukan dengan menggunakan uji statistik KolmogorovSmirnov. Data dikatakan lulus uji normalitas apabila semua data berdistribusi normal yang ditunjukkan dengan nilaiSig $>\alpha$. Hasil uji normalitas dapat dilihat pada Tabel 5.

\section{Tabel 5.} Hasil Uji Normalitas

\begin{tabular}{llr}
\hline & & Unstandardized Residual \\
\hline $\mathrm{N}$ & & 61 \\
Normal Parameters ${ }^{a, b}$ & Mean & 0,0000000 \\
& Std. Deviation & 0,73967021 \\
Most Extreme & Absolute & 0,105 \\
Differences & Positive & 0,105 \\
& Negative & $-0,098$ \\
Kolmogorov-Smirnov $Z$ & & 0,817 \\
Asymp. Sig. (2-tailed) & & 0,517 \\
\hline Sumber: Data diolah, 2018 & &
\end{tabular}

Berdasarkan Tabel 5 dapat diketahui bahwa hasil dari uji normalitas menunjukkan seluruh data yang digunakan dalam penelitian ini telah berdistribusi normal. Hal ini dapat dibuktikan dari nilai Asymp. Sig. (2-tailed) sebesar 0,517, lebih besar dari $\alpha=0,05$. 
Uji multikolinearitas dilakukan dengan melihat nilai tolerance dan nilai variance inflation factor (VIF). Apabila nilai torelance lebih dari atau sama dengan $10 \%(\geq 0,10)$ atau nilai variance inflation factor (VIF) kurang dari atau sama dengan 10 ( $\leq 10)$ maka dapat dikatakan bahwa model tersebut tidak ada gejala multikolinearitas (Ghozali, 2016:105). Hasil uji multikolinearitas dapat dilihat pada Tabel 6.

Tabel 6. Hasil Uji Multikolinearitas

\begin{tabular}{lcc}
\hline \multirow{2}{*}{ Model } & \multicolumn{2}{c}{ Collinearity Statistic } \\
\cline { 2 - 3 } & Tolerance & VIF \\
\hline Good Corporate Governance & 0,952 & 1,051 \\
Budaya Tri Hita Karana & 0,952 & 1,051 \\
\hline Sumber: Data diolah, 2018 & \multicolumn{2}{c}{}
\end{tabular}

Berdasarkan Tabel 6 dapat diketahui bahwa nilai tolerance kedua variabel bebas baik variabel good corporate governance maupun variabel budaya tri hita karana lebih dari 0,1 yaitu sebesar 0,952, dan nilai VIF kedua variabel bebas dalam penelitian ini kurang dari 10 yaitu sebesar 1,051. Maka dapat disimpulkan bahwa tidak terjadi gejala multikolinearitas antar variabel bebas dalam penelitian ini.

Uji heteroskedastisitas dilakukan dengan menggunakan model glejser. Jika nilai signifikansi lebih dari 0,05 maka tidak terdapat heteroskedastisitas, sedangkan jika nilai signifikansi lebih kecil dari 0,05 maka terdapat heteroskedastisitas. Hasil uji heteroskedastisitas dapat dilihat pada Tabel 7. 
Tabel 7.

Hasil Uji Heteroskedastisitas

\begin{tabular}{|c|c|c|c|c|c|c|}
\hline \multirow{2}{*}{\multicolumn{2}{|c|}{ Model }} & \multicolumn{2}{|c|}{$\begin{array}{c}\text { Unstandardized } \\
\text { Coefficients }\end{array}$} & \multirow{2}{*}{$\begin{array}{c}\text { Standardized } \\
\text { Coefficients } \\
\text { Beta }\end{array}$} & \multirow[t]{2}{*}{$T$} & \multirow[t]{2}{*}{ Sig. } \\
\hline & & $B$ & Std. Error & & & \\
\hline & (Constant) & 6,363 & 1,364 & & 4,666 & 0,000 \\
\hline & Good Corporate Governance & $-0,022$ & 0,083 & $-0,302$ & $-0,258$ & 0,125 \\
\hline & Budaya Tri Hita Karana & $-0,109$ & 0,276 & $-0,463$ & $-0,395$ & 0,112 \\
\hline
\end{tabular}

Sumber: Data diolah, 2018

Berdasarkan Tabel 7 dapat diketahui bahwa nilai signifikansi (Sig.) dari kedua variabel bebas, baik good corporate governance maupun budaya tri hita karana lebih dari $0,05(>0,05)$ yaitu nilai signifikansi variabel good corporate governance sebesar 0,125 dan nilai signifikansi variabel budaya tri hita karana sebesar 0,112 . Hal ini menunjukkan bahwa tidak terdapat gejala heteroskedastisitas pada model regresi yang digunakan dalam penelitian ini.

Analisis regresi linier berganda digunakan untuk mengetahui pengaruh satu atau lebih variabel bebas terhadap variabel terikat. Hasil analisis regresi linier berganda dapat dilihat pada Tabel 8 .

Tabel 8.

Hasil Analisis Regresi Linier Berganda

\begin{tabular}{|c|c|c|c|c|c|}
\hline \multirow[t]{2}{*}{ Model } & \multicolumn{2}{|c|}{$\begin{array}{c}\text { Unstandardized } \\
\text { Coefficients }\end{array}$} & \multirow{2}{*}{$\begin{array}{c}\begin{array}{c}\text { Standardized } \\
\text { Coefficients }\end{array} \\
\text { Beta }\end{array}$} & \multirow[t]{2}{*}{$t$} & \multirow[t]{2}{*}{ Sig. } \\
\hline & $B$ & Std. Error & & & \\
\hline 1 (Constant) & $-34,584$ & 2,594 & & $-13,331$ & 0,000 \\
\hline Good Corporate Governance & 0,061 & 0,016 & 0,222 & 3,827 & 0,000 \\
\hline Budaya Tri Hita Karana & 0,839 & 0,053 & 0,925 & 15,963 & 0,000 \\
\hline Adjusted R Square & 0,808 & & & & \\
\hline $\mathrm{F}$ & 127,467 & & & & \\
\hline Sig. F & $0,000^{\mathrm{a}}$ & & & & \\
\hline
\end{tabular}

Sumber: Data diolah, 2018

Berdasarkan Tabel 8 dapat dibentuk persamaan regresi dalam penelitian ini sebagai berikut. 
ISSN: 2302-8556

$$
\mathrm{Y}=-34,584+0,061 \mathrm{X}_{1}+0,839 \mathrm{X}_{2}+e
$$

Berdasarkan persamaan regresi yang terbentuk, maka dapat diinterpretasikan beberapa hal sebagai berikut. Nilai konstanta $(\alpha)$ sebesar $-34,584$. Hal ini berarti bahwa apabila variabel good corporate governance dan budaya tri hita karana konstan, maka kinerja keuangan LPD di Kabupaten Jembrana akan menurun. Nilai koefisien regresi variabel good corporate governance $\left(\beta_{1}\right)$ sebesar 0,061 . Nilai koefisien yang positif menunjukkan bahwa semakin baik penerapan good corporate governance, maka akan semakin meningkat kinerja keuangan LPD di Kabupaten Jembrana dengan asumsi variabel bebas lainnya dianggap konstan. Nilai koefisien regresi variabel budaya tri hita karana $\left(\beta_{2}\right)$ sebesar 0,839 . Nilai koefisien yang positif menunjukkan bahwa semakin baik penerapan budaya tri hita karana, maka akan semakin meningkat kinerja keuangan LPD di Kabupaten Jembrana dengan asumsi variabel bebas lainnya dianggap konstan.

Berdasarkan Tabel 8 dapat diketahui nilai Adjusted $R$ Square sebesar 0,808. Hal ini menunjukkan bahwa 80,8\% variasi kinerja keuangan LPD di Kabupaten Jembrana dapat dijelaskan oleh variabel good corporate governance dan variabel budaya tri hita karana, sedangkan 19,2\% sisanya dijelaskan oleh faktor lainnya yang tidak dimasukkan dalam model penelitian ini.

Berdasarkan Tabel 8 dapat diketahui nilai signifikansi (Sig.) sebesar 0,000 yaitu lebih kecil dari 0,05. Hal ini berarti model regresi yang terbentuk layak digunakan sebagai alat analisis dalam menguji pengaruh variabel good corporate governance dan budaya tri hita karana pada variabel kinerja keuangan LPD di Kabupaten 
Jembrana. Dari nilai tersebut pula dapat ditarik kesimpulan bahwa variabel good corporate governance dan budaya tri hita karana berpengaruh secara serempak pada kinerja keuangan tiap LPD di Kabupaten Jembrana.

Berdasarkan Tabel 8 dapat diketahui bahwa nilai signifikansi (Sig.) dari kedua variabel bebas yaitu variabel good corporate governance dan budaya tri hita karana kurang dari 0,05 yaitu sebesar 0,000. Hal ini menunjukkan bahwa kedua variabel bebas dalam penelitian ini yaitu good corporate governance dan budaya tri hita karana berpengaruh secara parsial atau individual pada kinerja keuangan LPD di Kabupaten Jembrana.

Penelitian ini menunjukkan bahwa good corporate governance berpengaruh pada kinerja keuangan LPD di Kabupaten Jembrana. Hal ini dibuktikan dengan hasil pengujian regresi linier berganda, yang menunjukkan bahwa nilai signifikansi untuk variabel good corporate governance sebesar 0,000 lebih kecil dari 0,05. Hal ini berarti good corporate governance berpengaruh signifikan pada kinerja keuangan LPD di Kabupaten Jembrana. Nilai koefisien $(\beta)$ variabel good corporate governance sebesar 0,061, memiliki arti bahwa good corporate governance berpengaruh positif pada kinerja keuangan LPD di Kabupaten Jembrana, sehingga dapat disimpulkan bahwa $\mathrm{H}_{1}$ diterima. Semakin baik penerapan good corporate governance pada LPD maka semakin meningkat kinerja keuangan LPD di Kabupaten Jembrana.

Hasil penelitian ini mendukung hipotesis pertama yang menyatakan bahwa good corporate governance berpengaruh positif pada kinerja keuangan LPD di Kabupaten Jembrana. Hasil ini juga sejalan dengan hasil penelitian sebelumnya yang 
ISSN: 2302-8556

dilakukan oleh Rahmatika dkk. (2015), Dewi dan Putri (2014), Setyawan dan Putri (2013), Soti dan Gupta (2013), Sami et al. (2011), Frediawan (2008), Ristifani (2009), Hindistari dan Putri (2016), Klapper dan Love (2002) yang juga secara empiris membuktikan adanya pengaruh good corporate governance terhadap kinerja.

Penelitian ini menunjukkan bahwa budaya tri hita karana berpengaruh pada kinerja keuangan LPD di Kabupaten Jembrana. Hal ini dibuktikan dengan hasil pengujian regresi linier berganda, yang menunjukkan bahwa nilai signifikansi untuk variabel budaya tri hita karana sebesar 0,000 lebih kecil dari 0,05. Hal ini berarti budaya tri hita karana berpengaruh signifikan pada kinerja keuangan LPD di Kabupaten Jembrana. Nilai koefisien $(\beta)$ variabel budaya tri hita karana sebesar 0,839, memiliki arti bahwa budaya tri hita karana berpengaruh positif pada kinerja keuangan LPD di Kabupaten Jembrana, sehingga dapat disimpulkan bahwa $\mathrm{H}_{2}$ diterima. Semakin baik penerapan budaya tri hita karana pada LPD maka semakin meningkat kinerja keuangan LPD di Kabupaten Jembrana.

Hasil penelitian ini mendukung hipotesis kedua yang menyatakan bahwa budaya tri hita karana berpengaruh positif pada kinerja keuangan LPD di Kabupaten Jembrana. Hasil ini juga sejalan dengan hasil penelitian sebelumnya yang dilakukan oleh Sastra dan Erawati (2017) dengan hasil budaya THK berpengaruh positif signifikan pada kinerja keuangan LPD. Hasil penelitian Ehtesham et al. (2011), Ozigbo (2016), Surya et al. (2014), serta Putri, dkk. (2017) secara empiris juga membuktikan bahwa budaya berpengaruh positif signifikan pada kinerja perusahaan. 


\section{SIMPULAN}

Berdasarkan analisis data dan pembahasan yang sudah diuraikan, maka ditarik simpulan yaitu, (1) Good corporate governance berpengaruh positif pada kinerja keuangan LPD di Kabupaten Jembrana. Semakin baik penerapan good corporate governance pada pengelolaan LPD maka semakin meningkat kinerja keuangan LPD tersebut. (2) Budaya Tri Hita Karana berpengaruh positif pada kinerja keuangan LPD di Kabupaten Jembrana. Semakin baik penerapan budaya tri hita karana pada pengelolan LPD maka semakin meningkat kinerja keuangan LPD tersebut.

Berdasarkan hasil penelitian terbukti bahwa good corporate governance dan budaya tri hita karana berpengaruh positif pada kinerja keuangan LPD di Kabupaten Jembrana. Maka dari itu, disarankan kepada seluruh LPD untuk lebih meningkatkan penerapan good corporate governance dan budaya tri hita karana dalam pelaksanaan operasional LPD agar dapat meningkatkan kepercayaan seluruh pihak, sehingga pada akhirnya dapat meningkatkan kinerja keuangan LPD. Keterbatasan penelitian ini adalah hanya menggunakan Kepala LPD sebagai responden, maka dari itu disarankan kepada peneliti selanjutnya agar menambah responden penelitian atau menggunakan seluruh prajuru dan panureksa LPD sebagai responden penelitian, sehingga diperoleh data yang lebih valid dan reliabel. Selain itu, peneliti selanjutnya juga disarankan untuk menambah variabel independen yang dapat mempengaruhi kinerja keuangan LPD, serta tidak hanya menggunakan rasio return on assets tetapi lebih banyak menggunakan rasio-rasio lain yang juga dapat digunakan untuk mengukur kinerja keuangan LPD. 
ISSN: 2302-8556

E-Jurnal Akuntansi Universitas Udayana

Vol.27.1.April (2019): 90-118

\section{REFERENSI}

Adiputra, I. M. P. (2014). Budaya Tri Hita Karana Sebagai Pemoderasi Pengaruh Kompleksitas Tugas Terhadap Kinerja Internal Auditor. Jurnal Dinamika Akuntansi, 6(2), 191-206.

Ahrens, T., \& Mollona, M. (2007). Organisational Control as Cultural Practice-A Shop Floor Ethnography of A Sheffield Steel Mill. Accounting, Organizations and Society, 32, 305-331.

Ariyanto, D., Sari, M. M. R., \& Ratnadi, N. M. D. (2017). Budaya Tri Hita Karana Dalam Model UTAUT. Jurnal Akuntansi Multiparadigma, 8 (2), 227-429.

Baliberkarya.com. (2017). Akhirnya Ketua LPD Mendoyo Dauh Tukad Dipolisikan Nasabah.https://baliberkarya.com/index.php/read/2017/07/10/201707100010/A khirnya-Ketua-LPD-Mendoyo-Dauh-Tukad-Dipolisikan-Nasabah.html. Diakses 15 Maret 2018.

Brigham, \& Houston. (2010). Dasar-dasar Manajemen Keuangan Buku 1. Edisi 11. Jakarta: Salemba Empat.

Dewi, K. K., \& Putri, I. G. A. M. A. D. (2014). Pengaruh Penerapan Prinsip-prinsip GCG pada Kinerja Keuangan Lembaga Perkreditan Desa Kabupaten Gianyar Bali. E-Jurnal Akuntansi Universitas Udayana, 7 (3), hal.559-573.

Ehtesham, U. M., Muhammad, T. M., \& Muhammad, S. A. (2011). Relationship Between Organizational Culture and Performance Management Practices: A Case of University in Pakistan. Journal of Competitiveness, (4), hal.78-86.

Forum for Corporate Governance in Indonesia (FCGI). (2001). Seri Tata Kelola Perusahaan (Corporate Governance). Jakarta

Frediawan, R. (2008). Pengaruh Penerapan Prinsip Good Corporate Governance terhadap Kinerja Keuangan Perusahaan (Studi Kasus pada PT. Jamsostek Kantor Cabang II Bandung). Skripsi Fakultas Ekonomi Universitas Widyatama.

Ghozali, H. I. (2016). Aplikasi Analisis Multivariate dengan Program IBM SPSS 21. Semarang: Universitas Diponegoro.

Gunawan, K. (2009). Pengaruh Budaya Organisasi, Kepuasan Kerja dan Motivasi Kerja terhadap Gaya Kepemimpinan dan Kinerja Organisasi (Studi pada Lembaga Perkreditan Desa (LPD) di Bali). Jurnal Aplikasi Manajemen, 7(2), 441-449. 
Halimatusadiah, E., Sofianty, D., \& Ermaya, H. N. (2015). Effects of The Implementation of Good Corporate Governance on Profitability. European Journal of Business and Innovation Research, 3(4), 19-35.

Hindistari, R. R., \& Putri, I. G. A. M. A. D. (2016). Pengaruh Penerapan Prinsipprinsip Good Corporate Governance pada Kinerja Bank Perkreditan Rakyat Kabupaten Gianyar. E-Jurnal Akuntansi Universitas Udayana, 16 (1), 101-128.

Hofstede, G., Neuijen, B., Ohayv, D. D., \& Sanders, G. (1990). Measuring Organizational Cultures: A Qualitative and Quantitative Study across Twenty Cases. Administrative Science Quarterly, 35, 286-316.

Indrianto, Nur. (2000). An Empirical Study of Locus of Control and Cultural Dimensions and Moderating Variable of The Effect of Participative Budgeting on Job Performance and Satisfaction. Jurnal Ekonomi dan Bisnis Indonesia, 15 (1), 97-114.

Ismadi, G. (2016). Oknum Pegawai LPD Gelapkan Uang Nasabah. https://bali.antaranews.com/berita/90265/oknum-pegawai-lpd-gelapkan-uangnasabah. Diakses 15 Maret 2018.

Klapper, L. F., \& Love, I. (2002). Corporate Governance, Investor Protection, and Performance in Emerging Markets. The World Bank Development Research Group Policy Research Working Paper 2818, 23-64.

Komite Nasional Kebijakan Governance. (2006). Pedoman Umum Kebijakan Good Corporate Governance Indonesia. Jakarta.

Kristianto, Feri. (2018). Lembaga Perkreditan Desa: LPD Tumbuh Menggembirakan. http://kalimantan.bisnis.com/read/20180208/445/735896/lembaga-perkreditan-desa--lpd-tumbuh-menggembirakan. Diakses 16 Maret 2018.

Meitasari, I. G. A. S., \& Budiasih, I. G. A. N. (2016). Pengaruh Ukuran Perusahaan, Struktur Modal, dan Loan to Deposit Ratio pada Kinerja Keuangan. E-Jurnal Akuntansi Universitas Udayana, 16 (2), 1516-1543.

Mulyadi. (2007). Sistem Perencanaan dan Pengendalian Manajemen. Jakarta: Salemba Empat.

Mustikayani, N. L. P. D., \& Dwirandra, A. A. N. B. (2016). Budaya Tri Hita Karana sebagai Pemoderasi Kompleksitas Tugas dan Tekanan Waktu terhadap Kinerja Auditor. E-Jurnal Akuntansi Universitas Udayana, 16 (2), 1544-1573. 
ISSN: 2302-8556

E-Jurnal Akuntansi Universitas Udayana

Vol.27.1.April (2019): 90-118

Ozigbo, N. C. (2013). Impact of Organizational Culture and Technology on Firm Performance in The Service Sector. Communications of the IIMA, 13(1), 68-82.

Peraturan Daerah Provinsi Bali Nomor 3 Tahun 2017 Tentang Perubahan Atas Peraturan Daerah Provinsi Bali Nomor 8 Tahun 2002 tentang Lembaga Perkreditan Desa.

Putri, I G. A. M. A. D. (2013). Pengaruh Good Corporate Governance dan Kearifan Lokal terhadap Kinerja Lembaga Perkreditan Desa (LPD) di Kabupaten Badung. Laporan Tidak Dipublikasikan. Fakultas Ekonomi dan Bisnis Universitas Udayana Denpasar.

Putri, I. G. A. M. A. D. (2012). Peranan Good Corporate Governance dan Budaya terhadap Kinerja Organisasi. Jurnal Akuntansi Dan Bisnis, 7 (2), hal.193-204.

Putri, I. G. A. M. A. D., Ulupui, I. G. K. A., \& Wirawati, N. G. P. (2017). Pengaruh Good Corporate Governance dan Budaya Tri Hita Karana pada Kinerja Bank Perkreditan Rakyat. Jurnal Ilmiah Akuntansi Dan Bisnis, 12 (1), 17-24.

Rahayu, S., Yudi, \& Sari, D. P. (2016). Makna "Lain” Biaya pada Ritual Ngaturang Canang Masyarakat Bali. Jurnal Akuntansi Multiparadigma, 7(3), 388-404.

Rahmatika, N., Kirmizi, dan Agusti, R. 2015. Pengaruh Penerapan Prinsip-prinsip Good Corporate Governance terhadap Kinerja Keuangan Perusahaan (Studi pada PT Angkasa Pura II). Jurnal Akuntansi, 3 (2), hal.148-159.

Ristifani. (2009). Analisis Implementasi Prinsip-prinsip Good Corporate Governance (GCG) dan Hubungannya Terhadap Kinerja PT. Bank Rakyat Indonesia (Persero) Tbk. Jurnal Mahasiswa Fakultas Ekonomi Universitas Gunadarma.

Riana, I. G. (2011). Dampak Penerapan Kultur Lokal Tri Hita Karana terhadap Orientasi Kewirausahaan dan Orientasi Pasar. Jurnal Teknik Industri, 13 (1), hal.37-44.

Robbins, S. P. (Jusuf Udaya, Alih Bahasa). (1994). Teori Organisasi: Struktur, Desain dan Aplikasi. Jakarta: Arcan.

Sami, H., Wang, J., \& Zhou, H. (2011). Corporate Governance and Operating Performance of Chinese Listed Firms. Journal of International Accounting, Auditing and Taxation, 20, hal.106-114.

Sarafina, S., \& Saifi, M. (2017). Pengaruh Good Corporate Governance terhadap Kinerja Keuangan dan Nilai Perusahaan (Studi pada Badan Usaha Milik Negara 
(BUMN) yang Terdaftar di Bursa Efek Indonesia Periode 2012-2015). Jurnal Administrasi Bisnis, 50 (3), 108-117.

Sarbah, A., \& Xiao, W. (2015). Good Corporate Governance Structures: A Must for Family Businesses. Open Journal of Business and Management, 3, 40-57.

Sastra, I. M. B., \& Erawati, N. M. A. (2017). Pengaruh Penerapan Prinsip-prinsip Good Corporate Governance dan Budaya Tri Hita Karana pada Kinerja Keuangan. E-Jurnal Akuntansi Universitas Udayana, 19 (1), 421-451.

Setyawan, K. M., \& Putri, I. G. A. M. A. D. (2013). Pengaruh Good Corporate Governance Terhadap Kinerja Keuangan Lembaga Perkreditan Desa di Kecamatan Mengwi Kabupaten Badung. E-Jurnal Akuntansi Universitas Udayana, 5 (3), 586-598.

Siagian, S. P. (2011). Manajemen Sumber Daya Manusia. Jakarta: PT. Bumi Aksara

Sobirin, A. (2007). Budaya Organisasi. Yogyakarta: Penerbit UPP STIM YKPN

Soti, P., \& Gupta, S. K. (2013). Impact of Corporate Governance on The Financial Performance of Indian IT Companies Listed on Stock Exchanges. International Journal of Management Research and Reviews, 3 (3), 2635-2647.

Suardhika, I. M. S. (2011). Pengaruh Implementasi Budaya Tri Hita Karana terhadap Penggunaan Sistem Informasi Akuntansi Dimediasi Keyakinan Diri Atas Komputer, Keinovatifan Personal, Persepsi Kegunaan, dan Persepsi Kemudahan Penggunaan pada Bank Perkreditan Rakyat di Bali. Disertasi Doktor Program Doktor Ilmu Akuntansi Pascasarjana Fakultas Ekonomi Universitas Brawijaya, Malang.

Suardikha, I. M. S. (2013). Pengaruh Budaya Tri Hita Karana terhadap Penggunaan Sistem Informasi Akuntansi Dimediasi Persepsi Kegunaan dan Persepsi Kemudahan Penggunaan. Jurnal Akuntansi dan Keuangan Indonesia, 10(1), 102-128.

Sucipto. (2003). Penilaian Kinerja Keuangan. Jurnal Akuntansi Fakultas Ekonomi Universitas Sumatera Utara, hal.1-12.

Sugiyono. (2017). Metode Penelitian Kuantitatif, Kualitatif, dan R\&D. Bandung: C. V Alfabeta

Surya, I. B. K., Thoyib, A., Fatchan, A., \& Mintarti, R. (2014). Tri Hita Karana Culture Effect on Company Performance, Leadership and Organizational 
ISSN: 2302-8556

Commitment (Studies an Regional Water Company in Bali Province). International Journal of Business and Management Invention, 3 (6), 13-22.

Tenaya, G. A. I. (2007). Analisis Falsafah dan Konsep Akuntansi dalam Perspektif Filsafat Kultur Bali Tri Hita Karana dan Kesadaran Internal Lembaga Terhadap Hukum Perusahaan. Tesis Program Pascasarjana Universitas Brawijaya, Malang.

Tim Studi Pengkajian Penerapan Prinsip-Prinsip OECD 2004 dalam Peraturan BAPEPAM mengenai Corporate Governance. (2006). Studi Penerapan PrinsipPrinsip OECD 2004 dalam Peraturan BAPEPAM mengenai Corporate Governance.

Todorovic, I. (2013). Impact of Corporate Governance on Performance of Companies. Montenegrin Journal of Economics, 9 (2), 47-53.

Yandazfar, D. (2013). Profitability Determinants Among Micro Firms: Evidence from Swedish Data. International Journal of Managerial Finance, 9 2), 151160. 